\title{
Comment
}

\section{Smoking and health promotion in Nazi Germany}

\author{
George Davey Smith, Sabine A Ströbele, Matthias Egger
}

In his recent paper in this journal "A birth cohort analysis of the smoking epidemic in West Germany", Brenner ${ }^{1}$ presents data showing that smoking rates increased dramatically from the late 1920 s onwards and that the reductions now being seen are limited to men with higher education. His conclusions are that intensified education programmes are required among teenagers, together with restrictive smoking policies at the workplace and on transportation systems. Brenner believes that the relatively limited progress made against smoking in Germany is due to the slow adoption of antismoking campaigns compared with other countries such as the USA. In this commentary we show that, contrary to these assertions, energetic antismoking campaigns were adopted in Germany at a very early stage. Indeed, all of the activities Brenner now commends were vigorously implemented during the Nazi period in Germany, with, as he clearly demonstrates, little effect on stemming the growing tide.

\section{Smoking and health: the German contribution}

While accusations about the health damaging effects of tobacco stretch back over the centuries, ${ }^{2-4}$ a particularly strong tradition of scientific investigation emerged in Weimar Germany and was developed during the Nazi period. Take, for example, the case of smoking and lung cancer. While there were earlier anecdotal reports, from Germany and elsewhere, commenting on a possible link, ${ }^{5-7}$ the 1928 study by Schönherr in Chemnitz ${ }^{8}$ is considered seminal ${ }^{9}$ in focussing on the smoking habits of a series of lung cancer patients. The small group of women in this series apparently did not smoke, but, Schönherr concluded, their cancers could have been caused by inhalation of their husbands' smoke. A case series, originating from Vienna and published in the Munich Medical Fournal in $1936,{ }^{10}$ reported a high prevalence of heavy smoking among patients with lung cancer. The author concluded that although it was not completely proved that smoking was the cause, this was most likely. As in the Chemnitz series, however, no controls were studied.

From the late 1920s on, Fritz Lickint published a series of detailed reviews of smoking and lung cancer trends, of ecological associ- ations, autopsy series, experimental animal studies, and clinical reports, ${ }^{112}$ which, he already considered in $1929,{ }^{11}$ left no doubt that tobacco smoke was a major cause of lung cancer. In 1939, Franz Müller, from Cologne, performed what is generally recognised as the earliest controlled study, in which the smoking histories of 86 male lung cancer cases were compared with those of 86 ill defined control subjects. ${ }^{13}$ A markedly higher proportion of the former were found to be heavy smokers.

This activity occurred against a backdrop of official concern regarding the health damaging effects of smoking. Conti, the Reich Health Führer, established the "Bureau Against the Dangers of Alcohol and Tobacco" in 1939. ${ }^{14}$ In 1942 an "Institute for the Struggle against the dangers of Tobacco" was established at the University of Jena, ${ }^{15}$ under the directorship of Professor Karl Astel. Originating from this institute in 1943 was the first formal casecontrol study of smoking and lung cancer, ${ }^{16}$ a convincing investigation in which Schairer and Schöniger showed a sophisticated understanding of the potential biases which could distort the findings. They included both population and clinical control series and examined whether changes in smoking pattern consequent upon illness could lead to artefactual results. It can now be calculated that the doseresponse association between smoking behaviour and lung cancer risk in their study is significant at the $p<0.0000001$ level. The institute from which this study came was supported by 100000 Reichsmark of Adolf Hitler's personal finances. ${ }^{14}$

The investigation of the health effects of smoking was not restricted to lung cancer. The 1938 annual report of the Public Health Service (Öffentliche Gesundheitsdienst) considered that "the nervous disorders of every sort which are being reported in increasing numbers from nearly every part of Germany are for the largest part due to excessive indulgence in tobacco and alcohol"'. ${ }^{17}$ In 1939, Lickint's monumental 800 page study "Tabak und Organismus" was published by Hippokrates Verlag, ${ }^{18}$ the editorship of which the censorious Kurt Klare had taken over from Erwin Liek, a doyen of Nazi medicine from the early years. ${ }^{14}$ This reviewed a huge body of work on the association between smoking and ill health, much of it carried out or published in Germany. In the same year, research into the effect of smoking on chromo- 
somes was commissioned by the Reich Health Office. ${ }^{14}$ Tobacco had long been considered a potential "genetic poison" by the Racial Hygiene movement in Germany; clearly the high level of concern regarding the health effects of smoking was strongly connected to the goal of general improvement of the Aryan "race". Thus Professor Karl Astel, SS member and director of the Jena Institute for Racial Policy and Human Genetics as well as the Institute for the Struggle Against the Dangers of Tobacco, was renowned for striking cigarettes from students' mouths, as part of his campaign against "racial deterioration". 19 Astel's racial hygiene activities in Thüringen included the intense harrassment of Jews, homosexuals, and the mentally subnormal, the proposition of a "preventive death sentence" for antisocial elements considered to be potential murderers, and an active role in the establishment of the Nazi euthanasia programmes, in which over 70000 people deemed to be mentally or physically defective were murdered. ${ }^{14}$

In March 1939 there was an attendance of 15000 at a conference on the effects of tobacco and alcohol consumption. At this meeting Hans Reiter, president of the Reich Health Office, charged all the medical societies of Germany with the responsibility for determining scientifically the degree to which tobacco caused disease. ${ }^{20}$ At the official opening of the Institute for the Struggle Against the Dangers of Tobacco, Reiter outlined a research agenda which should guide its work: statistical inquiries, clinical research into the effects of tobacco in humans, and experimental animal research. ${ }^{15}$

\section{Health promotion under the Nazis}

The scientific research into the health effects of smoking went hand in hand with extensive health promotion activities aimed at reducing the prevalence of the habit. Popular health magazines such as Gesundes Volk (Healthy People: Journal for the Health and Entertainment of the Workforce), Volksgesundheit (People's Health), and Gesundes Leben (Healthy Life) contained warnings against the dangers of smoking. ${ }^{21}$ There was also a journal Die Volksgifte (The Popular Poisons) devoted to the campaign against alcohol and tobacco. ${ }^{14}$ General interest magazines and newspapers also drove home the message, which clearly meshed well with the goals of racial hygiene: the improvement of the national-biological resource of the health of the population.

Propaganda against smoking was also disseminated by the Hitler Youth and the League of German Girls. ${ }^{22}$ In 1939, Göring issued a decree forbidding the military to smoke on the streets, on marches, and on brief off duty periods ${ }^{23}$ and in the summer of 1942 the Federation of German Women launched a campaign against tobacco and alcohol abuse. ${ }^{24}$ Self restraint was supplemented through restaurants and cafés being forbidden to sell cigarettes to women customers. ${ }^{22}$ Smoking was banned - for pupils and teachers alike - in many schools. Teachers were also expected to set an example to pupils outside of school by not smoking. In July 1943, a law was passed forbidding tobacco use in public places by anyone under 18 years of age. ${ }^{25}$

Transportation, workplaces, and public buildings became targets for smoking reduction campaigns. Thus, it was considered criminal negligence if drivers were involved in accidents while smoking, ${ }^{26}$ and in 1944 smoking was banned on city trains and buses. ${ }^{14}$ Aside from work related antismoking propaganda, smoking was prohibited in many individual workplaces and public buildings, including government bureaux, ${ }^{26}$ hospitals, and rest homes. ${ }^{14}$

The advertising of tobacco products also came under strict control. Advertisements could not give the impression that smoking had any "hygienic values". ${ }^{27}$ Furthermore, tobacco manufacturers could not "represent the use of tobacco as a sign of manliness nor ridicule opponents of tobacco. They may not make advertising appeals to women and those interested in sports nor picture smokers at the wheel of the automobile". ${ }^{27}$

In accord with much current health promotion theory, there was considerable endorsement of the goal of smoking cessation from role models. Thus, Robert Ley, the leader of the German Labour Front, attested personally to the benefits of not smoking. ${ }^{20}$ While many other influential figures joined this roster, ${ }^{18}$ the star performer in antismoking propaganda was Adolf Hitler. As one magazine put it: "brother national socialist, do you know that your Führer is against smoking and thinks that every German is responsible to the whole people for all his deeds and omissions, and does not have the right to damage his body with drugs?". ${ }^{21}$

\section{Health promotion and the King Canute principle}

Brenner shows that despite this intense health promotion activity smoking continued to increase. This was recognised at the time, and it was perhaps with some glee that the Berlin correspondent for the fournal of the American Medical Association - a regular if somewhat cynical reporter on the crusade against tobacco - noted that cigarette consumption increased in 1938 from 609 per head to 676 per head. ${ }^{26}$

The processes acting in such a case have a more general form within health promotion, which can be termed the King Canute principle. In popular imagination (if not in mythology or fact $^{28}$ ), King Canute sat on the beach and, in order to demonstrate the enormity of his power, told the tide to stop coming in. His supposed failure in this enterprise is his lasting contribution to British folklore. Health promotion, on the other hand, has learnt from Canute's experiences, choosing instead to sit on the beach while the tide is going out and applauding. In this situation, it is then possible to claim that the ebbing tide is a direct outcome of the applause. Take, for example, the celebrated North Karelia heart disease prevention programme. Intensive efforts were made 


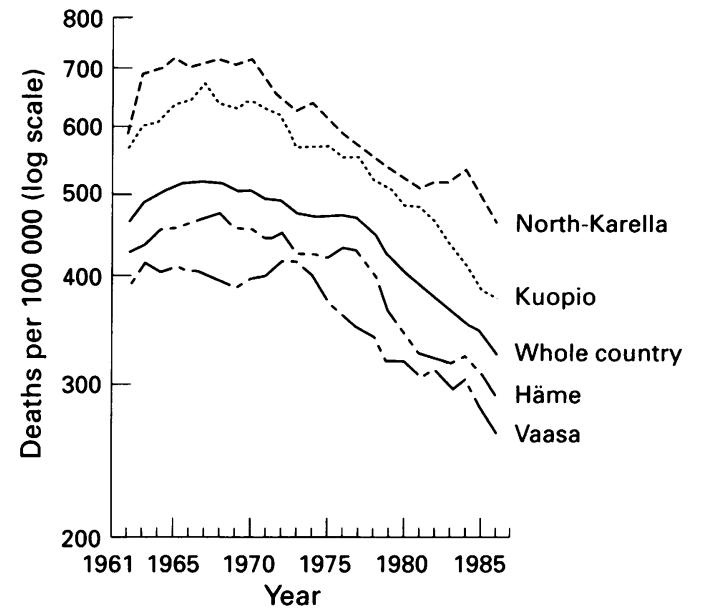

Age standardised mortality from ischaemic heart disease in selected counties in Finland 1961-87, three year moving averages, males aged 35-64. ${ }^{30}$

to modify the coronary risk factor profile in North Karelia in Finland from the early 1970s, and the success of the project was announced. ${ }^{29}$ As the figure shows, the declines in ischaemic heart disease mortality in North Karelia were no greater than elsewhere in Finland ${ }^{30}-$ it was simply that, unlike with King Canute, the proclamation that heart disease would be prevented was made just as the tide of ischaemic heart disease was beginning to ebb.

Others have been less fortunate. Some heart disease prevention programmes have been launched at a time when the secular trends in ischaemic heart disease mortality are unfavourable, with an apparent increase in disease rates being consequent on the activity of the health promoters. ${ }^{31}$ Thus, the National Myocardial Infarction Control Programme, launched in 1976 in the former East Germany, has run concurrently with increasing mortality from heart disease, while the 1978 initiative of a National Hypertension Control Programme has been followed by increasing stroke rates. ${ }^{32}$

\section{Resistance to health promotion}

In Nazi Germany, then, the efforts to prevent smoking occurred during a period when right across the western world cigarette smoking was increasing dramatically. The failure of the intensive efforts to reduce smoking are not surprising in these circumstances. Furthermore, there may have been some element of deliberate resistance to health promotion activities which were being so intensively supported by the state. This could partly reflect opposition to an authoritarian government. Certainly, the austerity measures introduced in the period leading up to and following the outbreak of the war were accompanied by sporadic displays of overt popular antipathy and more widespread grumbling discontent. ${ }^{22}$

This resistance was seen - and celebated - in other areas of Nazi health and population policy. Thus the emigré Jewish physician and energetic campaigner against the Nazi regime, Martin Gumpert, commented on the failure of the campaigns to increase the German birth rate: in his words, German women were "on strike". ${ }^{17} \mathrm{He}$ also discussed "the Führer's distaste for injurious smoking and drinking habits" which, it might be thought, would "produce beneficial results for the national economy and the national health". $\mathrm{He}$ considered that the large increase in alcohol consumption and drunkenness in Germany reflected "The abstinent Hitler, who from conviction never takes a drop of alcohol, and whose movement first emerged from the beer halls of Munich, now drives the people at whose head he stands into fatal alcoholism". ${ }^{17}$

\section{Conclusions}

The failure of smoking rates to fall in Germany in the way that they have fallen in several other countries is attributed by Brenner to the relative lack of public health initiatives aimed at preventing smoking in Germany. One of the reasons for the lack of such initiatives may be that the association of authoritarian antismoking efforts at workplaces, on public transport, and in schools with the Nazi regime remained for a long period in popular memory. This would be one of the many factors ${ }^{33}$ outside of the control of present day health promoters which affect whether people start smoking in the first place or stop once they have started. The history of smoking and health in Germany, which cannot be taken to start in the post war world with a population free of restrictions on smoking, shows the inadequacy of simple diffusion models, whether of research into public policy or of innovations in behaviour from the more educated to less educated sections of society.

1 Brenner H. A birth cohort analysis of the smoking epidemic in West Germany. $f$ Epidemiol Community Health 1993;47:54-8

2 Redmond DE. Tobacco and cancer: the first clinical report, 1761. New Engl f Med 1970;282:18-23.

3 Walker RB. Medical aspects of tobacco smoking and the anti-tobacco movement in Britain in the nineteenth cenanti-tobacco movement in Britain in the

4 Harley D. The beginnings of the tobacco controversy: Puritanism, James I, and the royal physicians. Bull Hist Muritanism, James I,

5 Adler I. Primary malignant growths of lung and bronchi. New York: Longmans, Green \& Co, 1912.

6 Fahr T. Discussion of paper by O Teutschlaender. Verh Dtsch Ges Pathol 1923;19:192.

7 Tylecote FE. Cancer of the lung. Lancet 1927;256-7.

8 Schönherr E. Beitrag zur Statistik und Klinik der Lungentumoren. $Z$ Krebsforsch 1928;27:436-50.

9 Larson PS, Haag HB, Silvette H. Tobacco: experimental and clinical studies. Baltimore: The Williams and Wilkin Company, 1961.

10 Fleckseder R. Ueber den Bronchialkrebs und einige seiner Entstehungsbedingungen. Munch Med Wschr 1936; 83:1585-8.

11 Lickint F. Tabak und Tabakrauch als aetiologischer Faktor des Carcinoms. $Z$ Krebsforsch 1929;30:349-65.

12 Lickint F. Der Bronchialkrebs der Raucher. Munch Med Wschr 1935;82:122-4

13 Müller FH. Tabakmissbrauch und Lungencarcinom. $Z$ Krebsforsch 1939;49:57-85.

14 Proctor RN. Racial hygiene. Medicine under the Nazis. Cambridge MA: Harvard University Press, 1988.

15 Reiter H. Ansprache bei der Eröffnung des 1. Wissenschaftlichen Instituts zur Erforschung der Tabakgefahren an der Friedrich-Schiller-Universität Jena am 5. April 1941 Munch Med Wschr 1941;88:697-9.

16 Schairer E, Schöniger E. Lungenkrebs und Tabakverbrauch. Z Krebsforsch 1943;54:261-9.

7 Gumpert M. Heil hunger! Health under Hitler. London: George Allen and Unwin Ltd, 1940.

18 Lickint F. Tabak und Organismus. Stuttgart: HippokratesVerlag, 1939.

19 Weindling P. Health, race and German politics between national unification and Nazism, 1870-1945. Cambridge: Cambridge University Press, 1989.

20 Anonymous. Berlin: Stimulants endanger public health. JAMA 1939;112:2339-40. 
21 Wuttke-Groneberg W. Medizin im Nationalsozialismus: ein arbeitsbuch. Wurmlingen: Schwabische Verlagsgesellschaft, 1982.

22 Charman T. The German home front 1939-1945. London: Barrie \& Jenkins, 1989.

23 Anonymous. Berlin: Alcohol, tobacco and coffee. $\mathcal{F} A M A$ 1939;113:1144-5.

24 Stephenson J. The Nazi organisation of women. London: Croom Helm, 1981.

25 Fromme W. Offentlicher Gesundheitsdienst. In: Rodenwaldt E, ed. Hygiene: Part 1. General Hygiene. Field waldt E, ed. Hygiene: Part 1. General Hygiene. Field ence 1939-1946. Wiesbaden: Dietrich'sche Verlagsbuchence 1939-1946.
handlung, 1948.

26 Anonymous. Berlin: Control of the use of alcohol and tobacco. FAMA 1939;113:2163-4.

27 Anonymous. Berlin: The nicotine content of tobacco products. FAMA 1939;113:1145-50.
28 Larson LM. Canute the Great. New York: GP Putnam \& Sons, 1912

29 Tuomilehto J, Geboers J, Salonen JT, Nissinen A, Kuulasmaa K, Puska P. Decline in cardiovascular mortality in North Karelia and other parts of Finland. $B M \mathcal{F}$ 1986;293:1068-71.

30 Valkonen T. Trends in regional and socio-economic mortality differentials in Finland. Int $\mathcal{f}$ Health Serv 1992;3/ 4:157-66.

31 Davey Smith G. Comprehensive cardiovascular community control programmes in Europe. Abstracts on Hygiene and Communicable Diseases 1989;64(5):R1-R3.

32 Barth W, Heinemann L. Result of a 20 -year MI and stroke control programme: increasing rates. Proceedings of the 3rd International Conference on Preventive Cardiology, Oslo 27th June-1 July 1993; 24.

33 Chapman S. Unravelling gossamer with boxing gloves: problems in explaining the decline in smoking. BMF 1993;307:429-32. 